\title{
Insect antifeedant potent quinoxalines
}

\author{
K. Lakshmanan ${ }^{1, *}$, K. G. Sekar ${ }^{1}$, V. Sathiyendiran ${ }^{2}$, I. Muthuvel ${ }^{3}$ \\ ${ }^{1}$ Department of Chemistry, National College, Tiruchirappalli - 620001, India. \\ ${ }^{2}$ Department of Chemistry, Sourashtra College, Madurai - 625004, India \\ ${ }^{3}$ Department of Chemistry, Annamalai University, Annamalainagar - 608002, India \\ *E-mail address: laksen_l@yahoo.co.in
}

\begin{abstract}
Some 6-substituted aryl quinoxalines have been prepared and their purities were checked by their physical constants and spectroscopic data reported earlier. The insect antifeedant activities of these quinolones were studied by leaf-discs bio assay method using $4^{\text {th }}$ instar larvae Achoea Janata L.
\end{abstract}

Keywords: 6-substituted aryl qyinoxalines; leaf-disc bio assay; Insect antifeedant activity

\section{INTRODUCTION}

Aryl quinoxalines are medicinally important bi nitrogen heterocyclic compounds due to the presence of this ring and polar substituents in numerous antibiotics [1,2]. The important biological activities of quinoxalines are antibacterial [2,3], antiviral [4], anti-inflammatory [4], askinase inhibitors [4], anticancer [4], antimycobacterial [5,6], antifungal [7], anthelmintic [4,7], antidepressants [8] and antitumor [9,10]. Many kinds of synthetic methods including solvent-free and catalysts were reported in the literature for synthesis of quinoxalines by the condensation of 1,2-diamines and 1,2-dicarbonyl compounds [1,2,11]. Generally compounds which are possess carbonyl, unsaturation moieties and polar substituents shows insect antifeedant activities [12]. Within this motivity, the authors wishes to examine the insect antifeedant activity of the synthesized quinoxaline derivatives. In-vitro and leaf-disc bioassay methods were adopted for evaluation of insect antifeedant $[13,14]$. Thirunarayanan [12] and his co-workers have studied the insect antifeedant activities of various substituted chalcones such as 1-naphthyl, 2-naphthyl, 4, 6-halogen substituted 1, 2naphthyl, 4,6-methoxy and methyl substituted 1,2-naphthyl, 9H-fluorenyl, 3,4-dichlorophenyl [15], 4'-fluorophenyl [16], 5-methyl-2-furyl [17], 2-phenothiazenyl [18], 2-benzimidzole [19], 1-methyl-2-pyrrolyl [20], 2,5-dimethyl-3-furyl [21], 2,5-dimethyl-3-thienyl [22], trichlorophenyls [23]. The acyl bromides and $\omega$-bromo ketones [24], acyl compounds such as 9H-fluorenacyl [25] also shows the insect antifeedant anctivities. The insect antifeedant activities of pyrazoline and their derivatives were studied by Thirunarayanan [26]. Lakshmanan et al have studied the insect antifeedant activities of trifluormethyl imines [27].

The halogen substituted epoxides possess insect antifeedant activity and it was studied by Thirunarayanan [28-30]. The insect antifeedant activities of di-imines [31], oxazines [32] and Tröger bases [33] were reported in literature. Recently, Thirunarayanan have evaluated 
the insect antifeedant activities of some substituted bicycle [2.2.1] heptane-5-ene methanones [34]. Within the above view, there is no report available for the study of insect antifeedant activity of aryl quinoxalines in the past in literature. Therefore, the authors have taken efforts to synthesis the substituted quinoxalines for studying the insect antifeedant activities using leaf-disc bio assay method using $4^{\text {th }}$ instar larvae Achoea Janata L.

\section{EXPERIMENTAL}

\section{1. Synthesis of substituted quinoxalines}

Aryl 5- and 6- substituted quinoxalines were prepared by literature method [35]. The purities of these quinoxalines have been examined by the characterization data reported earlier. The general structure of the 6-substituted quinoxalines is shown in Fig. 1.

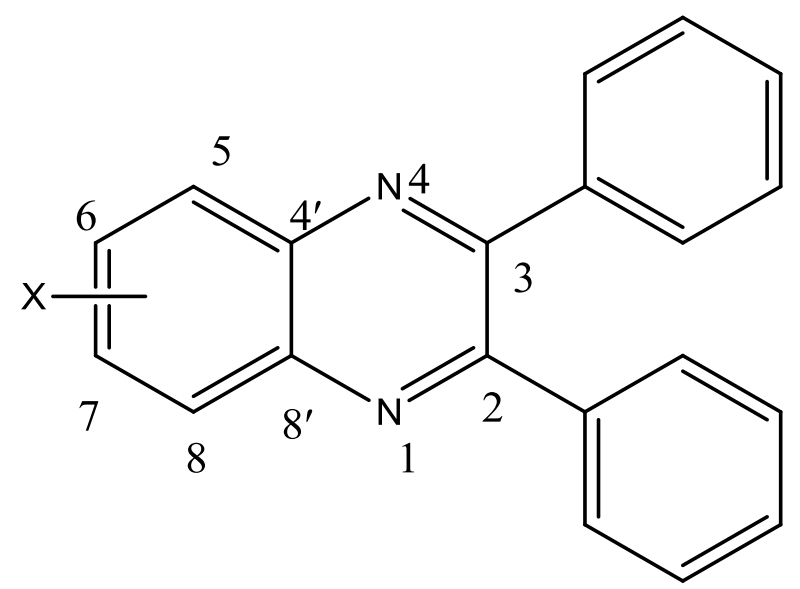

$\mathrm{X}=6-\mathrm{H}, 6-\mathrm{PhCO}, 6-\mathrm{Br}, 6-\mathrm{COOH}, 6-\mathrm{Cl}, 6-\mathrm{F}, 6-\mathrm{OCH}_{3}, 5-\mathrm{CH}_{3}, 6-\mathrm{CH}_{3}, 6-\mathrm{NO}_{2}$

Fig. 1. General structure of substituted quinoxalines.

\section{RESULTS AND DISCUSSION}

\section{1. Insect antifeedant activity}

Generally organic compounds which are having carbonyl, unsaturation and halogens they possess insect antifeedant activity. Therefore, the author wishes to examine the insect antifeedant activity of these substituted quinoxalines derivatives and found to be active as insect antifeedants. This test was performed with a $4^{\text {th }}$ instar larva Achoea janata $\mathrm{L}$ against castor semilooper, were reared as described on the leaves of castor, Ricinus communis in the laboratory at the temperature range of $26{ }^{\circ} \mathrm{C} \pm 1{ }^{\circ} \mathrm{C}$ and a relative humidity of $75-85 \%$. The leaf - disc bioassay method $[12,30,34]$ was used against the $4^{\text {th }}$ instar larvae to measure the antifeedant activity. The $4^{\text {th }}$ instar larvae were selected for testing because the larvae at this stage feed very voraciously.

\section{2. Measurement of insect antifeedant activity of quinoxalines}

Castor leaf discs of a diameter of $1.85 \mathrm{~cm}$ were punched and intact with the petioles. All synthesized quinoxalines were dissolved in acetone at a concentration of $200 \mathrm{ppm}$ dipped 
for 5 minutes. The leaf discs were air-dried and placed in one liter beaker containing little water in order to facilitate translocation of water.

Therefore, the leaf discs remain fresh throughout the duration of the rest, $4^{\text {th }}$ instar larvae of the test insect, which had been preserved on the leaf discs of all quinoxalines and allowed to feed on them for $24 \mathrm{~h}$. The areas of the leaf disc consumed were measured by leafdisc bio assay method [12,30,34]. The observed antifeedant activity of 5-and 6- substituted quinoxalines derivatives was presented in Table 1.

Table 1. The insect antifeedant activities of 5-and 6- substituted quinoxalines derivatives.

\begin{tabular}{|c|c|c|c|c|c|c|c|c|c|c|c|}
\hline Entry & $\mathrm{R}$ & $\begin{array}{c}4-6 \\
\mathrm{pm}\end{array}$ & $\begin{array}{c}6-8 \\
\mathrm{pm}\end{array}$ & $\begin{array}{c}8-10 \\
\mathrm{pm}\end{array}$ & $\begin{array}{c}10 \\
\mathrm{pm}- \\
12 \\
\mathrm{am}\end{array}$ & $\begin{array}{c}12-6 \\
\mathrm{am}\end{array}$ & $\begin{array}{c}6-8 \\
\mathrm{am}\end{array}$ & $\begin{array}{c}8 \\
\mathrm{am}- \\
12 \\
\mathrm{pm}\end{array}$ & $\begin{array}{c}12 \\
\mathrm{am}- \\
2 \mathrm{pm}\end{array}$ & $\begin{array}{c}2-4 \\
\mathrm{pm}\end{array}$ & $\begin{array}{c}\text { Total leaf } \\
\text { disc } \\
\text { consumed } \\
\text { by 24h }\end{array}$ \\
\hline 1 & $\mathrm{H}$ & 1 & 1 & 1 & 0.5 & 0.5 & 1 & 1 & 1 & 1 & 8 \\
\hline 2 & $6-\mathrm{COPh}$ & 1 & 1 & 2 & 1 & 1 & 0 & 1 & 1 & 1 & 9 \\
\hline 3 & $6-\mathrm{Br}$ & 0.5 & 0.25 & 0 & 0.25 & 0.5 & 0.5 & 0.5 & 1 & 1 & 4 \\
\hline 4 & $6-$ & 1 & 1 & 1 & 1 & 0 & 0 & 1 & 1 & 1 & 7 \\
\hline 5 & $6-\mathrm{Cl}$ & 0.5 & 0.5 & 0.5 & 0 & 0 & 0 & 0.5 & 0.5 & 0.5 & 3 \\
\hline 6 & $6-\mathrm{F}$ & 0.5 & 0.5 & 0.5 & 0.25 & 0.25 & 0 & 0 & 1 & 0.5 & 3.5 \\
\hline 7 & $6-\mathrm{OCH}_{3}$ & 1 & 1 & 0 & 1 & 1 & 1 & 1 & 1 & 1 & 8 \\
\hline 8 & $5-\mathrm{CH}_{3}$ & 1 & 0.5 & 1 & 1 & 1 & 0.5 & 1 & 0.5 & 0.5 & 7 \\
\hline 9 & $6-\mathrm{CH}_{3}$ & 2 & 1 & 0 & 1 & 1 & 1 & 0 & 1 & 1 & 8 \\
\hline 10 & $6-\mathrm{NO}_{2}$ & 1 & 1 & 1 & 1 & 0.5 & 0.5 & 0.5 & 0.5 & 1 & 7 \\
\hline
\end{tabular}

Number of leaf discs consumed by the insect (values are mean + SE of five).

The results of the antifeedant activity of substituted quinoxalines are presented in Table 1 reveals that compounds $\mathbf{3 , 5}$ and $\mathbf{6}$ were found to reflect satisfactory antifeedant. This test is performed with the insects which ate only two-leaf disc soaked under the solution of this compound.

Compound $\mathbf{6}$ showed enough antifeedant activity but lesser than $\mathbf{5}$. Further compound $\mathbf{5}$ was subjected to measure the antifeedant activity at different 50,100,150 ppm concentrations and the observation reveals that as the concentrations decreased, the activity also decreased. It is observed from the results in Table 2 and that the 5 6-chloro-2,3-diphenylquinoxaline showed an appreciable antifeedant activity at $150 \mathrm{ppm}$ concentration. 
Table 2. Antifeedant activity of compound 5 6-chloro-2,3-diphenylquinoxaline showed an appreciable antifeedant activity at 3 different concentrations.

\begin{tabular}{|c|c|c|c|c|c|c|c|c|c|c|}
\hline $\mathrm{ppm}$ & $\begin{array}{c}4-6 \\
\mathrm{pm}\end{array}$ & $\begin{array}{c}6-8 \\
\mathrm{pm}\end{array}$ & $\begin{array}{c}8-10 \\
\mathrm{pm}\end{array}$ & $\begin{array}{c}10 \mathrm{pm} \\
-12 \\
\mathrm{am}\end{array}$ & $\begin{array}{c}12-6 \\
\mathrm{am}\end{array}$ & $\begin{array}{c}6-8 \\
\mathrm{am}\end{array}$ & $\begin{array}{c}8 \mathrm{am}- \\
12 \mathrm{pm}\end{array}$ & $\begin{array}{c}12 \mathrm{pn}- \\
2 \mathrm{pm}\end{array}$ & $\begin{array}{c}2-4 \\
\mathrm{pm}\end{array}$ & $\begin{array}{c}\text { Total leaf } \\
\text { disc } \\
\text { consumed } \\
\text { by 24h }\end{array}$ \\
\hline 50 & 0.5 & 0.25 & 0.25 & 0 & 0 & 0 & 0 & 0 & 0 & 1 \\
\hline 100 & 0.5 & 0.5 & 0.25 & 0 & 0 & 0 & 0 & 0 & 0 & 1.25 \\
\hline 150 & 0 & 0 & 0.25 & 0 & 0 & 0 & 0 & 0 & 0 & 0.25 \\
\hline
\end{tabular}

Number of leaf discs consumed by the insect (values are mean $+\mathrm{SE}$ of five).

\section{CONCLUSIONS}

A series of 5,6-substituted 2,3-diphenyl quinoxaline derivatives have been synthesized and examined their purities with their physical constants and spectroscopic data reported in earlier. The insect antifeedant activities of quinoxalines have been evaluated using leaf-disc bioassay method. The quinoxaline 5 6-chloro-2,3-diphenylquinoxaline showed an appreciable antifeedant activity.

\section{ACKNOWLEDGMENT}

The authors acknowledged Dr. G. Thirunarayanan, Assistant Professor of Chemistry, Annamalai University, Annamalainagar - 608002, India for his valuable helps for completion of this work.

\section{References}

[1] A. R. Bendale, D. Kotak, D. P. Damahe, S. P. Narkhede, A. G. Jadhav and G. Vidyasagar, Der Chemica Sinica. 2 (2011) 20-22.

[2] A. Hasaninejad, A. Zare, M. R. Mohammadizadeh and M. Shekouhy, Green Chem. Lett. Rev. 3 (2010) 143-148.

[3] M. M. Badran, A. A. Moneer, H. M. Refaat and A. A El-Malah, J. Chin. Chem. Soc. 54 (2007) 469-478.

[4] W. He, M. R. Meyers, B. Hanney, A. Spada, G. Blider, H. Galzeinski, D. Amin, S. Needle, K. Page, Z. Jayyosi and H. Perrone, Bioorg. Med. Chem. Lett. 13 (2003) 30973100 .

[5] K. Waisser, Z. Odlerova, R. Beckert and R. Mayer, Pharmazie. 44 (1989) 234-235.

[6] L. E. Seitz, W. J. Suling and R. C. Reynolds, J. Med. Chem. 45 (2002) 5604-5606.

[7] G. Sakata, K. Makino and Y. Karasawa, Heterocycles. 27 (1988) 2481-2515.

[8] R. Sarges, H. R. Howard, R. C. Browne, L. A. Label and P. A. Seymour, J. Med. Chem. 33 (1990) 2240-2254. 
[9] S. T. Hazeldine, L. Polin, J. Kushner, J. Paluch, K. White, M. Edelstein, E. Palomino, T. H. Corbett and J. P. Horwitz, J. Med. Chem. 44 (2001) 1758-1776.

[10] S. T. Hazeldine, L. Polin, J. Kushner, K. White, N. M. Bouregeois, B. Crantz, E. Palomino, T. H. Corbett and J. P. Horwitz, J. Med. Chem. 45 (2002) 3130-3137.

[11] H. Xu, W. M. Liao and H. F. Li, Ultrason. Sonochem. 14 (2007) 779-782.

[12] G. Thirunarayanan, J. Indian Chem. Soc. 85(4) (2008) 447-451.

[13] Y. S. Nalwar, M. A. Sayyed, S.S. Mokle,P. R. Zanwar and Y. B. Vibhute , World. J. Chem. 4 (2009) 123-126.

[14] D. Dasharathi, R. Netaji, M. A. Basheer and Y. B. Vibhute, Ultra Sci, 17(1) (2005) 89 92.

[15] G. Thirunarayanan, S. Surya, S. Srinivasan, G. Vanangamudi and V. Sathiyendiran, Spectrochim. Acta (A) 75 (2010) 152-156.

[16] G. Thirunarayanan and G. Vanangamudi, Arabian J. of Chem. (2010); doi:10.1016/j.arabjc.2010.10.034.

[17] G. Thirunarayanan, G. Vanangamudi and M. Subramanian, Elixir Org. Chem. 43 (2012) 6987-6989.

[18] K. Ranganathan, R. Suresh, D. Kamalakkannan, R. Arulkumaran, R. Sundararajan, S. P. Sakthinathan, S. Vijayakumar, G. Vanangamudi, K. Thirumurthy, P. Mayavel and G. Thirunarayanan, International Letters of Chemistry, Physics and Astronomy 4 (2012) 66-75.

[19] P. Janaki, K. G. Sekar, G. Thirunarayanan, J. Saudi Chem. Soc. 2013. Doi.10.1016/j.jscs.2012.11.013

[20] G. Thirunarayanan, G. Vanangamudi and M. Subramanian, Org. Chem.: An Indian J. 9(1) (2013) 1-16.

[21] M. Subramanian, G. Vanangamudi and G. Thirunarayanan, Spectrochim Acta. 110A (2013) 116-123.

[22] G. Vanangamudi, M. Subramanian and G. Thirunarayanan, Arabian J. Chem. (2013). DOI: $10.1016 / j$.arabjc.2013.03.006.

[23] R. Sundararajan, R. Arulkumaran, S. Vijayakumar, D. Kamalakkannan, R. Suresh, S. John Joseph, K. Ranganathan, SP. Sakthinathan, G. Vanangamudi, G. Thirunarayanan, International Letters of Chemistry, Physics and Astronomy 1 (2014) 67-73.

[24] G. Thirunarayanan, J. Saudi Chem. Soc. (2011). doi:10.1016/j.jscs.2011.12.003

[25] G. Thirunarayanan, Q-Science Connect. (2013):6; http://dx.doi.org/10.5339,2013.6

[26] G. Thirunarayanan, International Letters of Chemistry, Physics and Astronomy 18 (2014) 47-56.

[27] G. Thirunarayanan, P. Mayavel, K. Thirumurthy, G. Vanangamudi, K. Lakshmanan and K. G. Sekar, Int. J. Chem. 1(2) (2012) 166-172.

[28] G. Thirunarayanan, J. Saudi Chem. Soc. (2011), doi:10.1016/j.jscs.2011.10.011

[29] G. Thirunarayanan and G. Vanangamudi, Arab J. Chem. (2011). doi:10.1016/j.arabjc.2011.03.020 
[30] G. Thirunarayanan and G. Vanangamudi, Spectrochim Acta. 81A (2011) 390-396.

[31] G. Thirunarayanan, Bull. Chem. Soc. Ethiop. 28(1) (2014) 73-79

[32] G. Thirunarayanan, V. Renuka, K. G. Sekar, K. Lakshmanan, K. Anbarasu, International Letters of Chemistry, Physics and Astronomy 4 (2014) 66-81.

[33] G. Thirunarayanan, Arabian J. Chem. (2012). doi.org/10.1016/j.arabjc.2012.10.025.

[34] G. Thirunarayanan, Q-Science Connect, 2014;

DOI: http://dx.doi.org/10.5339/connect.2014.18

[35] G. Thirunarayanan, I. Muthuvel, V. Sathiyendiran, International Letters of Chemistry, Physics and Astronomy 19(2) (2014) 198-207 